\title{
PERTUMBUHAN SANSEVIERIA PADA BEBERAPA KOMPOSISI MEDIA TANAM MENGGUNAKAN TPA SAMPAH (TPA-S) KOTA PEKANBARU
}

\author{
Sansevieria Growth in Some Compositions of Plant Media \\ Using TPA Waste (Tpa-S) Kota Pekanbaru \\ Hanifa Rahma Fitri ${ }^{1}$, Tengku Nurhidayah ${ }^{2}$ \\ ${ }^{1)}$ Mahasiswa Jurusan Agroteknologi, Fakultas Pertanian, Universitas Riau \\ ${ }^{2)}$ Dosen jurusan Agroteknologi, Fakultas Pertanian, Universitas Riau \\ Email: hanifarahmafitri@gmail.com/ 082384627553 \\ [Diterima: Desember 2019; Disetujui: April 2020]
}

\begin{abstract}
This study aims to examine the best composition of the planting media using the landfill soil (TPA-S) for the growth of Sansevieria species S. aubrytiana 'Tiger' and S. trifasciata 'Laurentii'. This research was conducted at the greenhouse of the Faculty of Agriculture, University of Riau. This research was carried out experimentally by using a Completely Randomized Design (factorial) consisting of two factors. The first was plant type (S) and then planting media (M), consisting of 6 treatments and 3 replications, so that 18 research units were obtained. The treatments consisted of M1S1 (100\% landfill soil, type S. aubrytiana 'Tiger'), M2S1 (70\% landfill soil + 30\% TKKS compost, type S. aubrytiana 'Tiger'), M3S1 (70\% landfill soil + $30 \%$ husk charcoal, type S. aubrytiana 'Tiger'), M1S2 (100\% landfill soil, type S. trifasciata 'Laurentii'), M2S2 (70\% landfill soil $+30 \%$ TKKS compost, type $S$. trifasciata 'Laurentii') and M3S2 (70\% landfill soil + 30\% husk charcoal, type $S$. trifasciata 'Laurentii'). The data obtained were then further tested by Duncan's multiple range test (DNMRT) at the 5\% of confidant level. The results showed that the landfill could be an alternative substitute for top-soil as a planting medium for ornamental plants, especially for two types of Sansevieria plants. The combinations planting media 70\% soil of landfill $+30 \%$ TKKS compost could increase plant height, leaf width, and the number of plant leaves in both types of Sansevieria plants. Whereas the combination of $70 \%$ soil of landfill $+30 \%$ husk charcoal could increase the number of tillers, fresh weight of plants, and root volume in both types of Sansevieria plants.
\end{abstract}

Keywords: Sansevieria, Landfill, TKKS compost, Husk charcoal.

\begin{abstract}
ABSTRAK
Penelitian ini bertujuan untuk mengetahui komposisi media tanam menggunakan tanah Tempat Pembuangan Akhir Sampah (TPA-S) yang terbaik utuk pertumbuhan tanaman Sansevieria jenis Sansevieria aubrytiana 'Tiger' dan Sansevieria trifasciata 'Laurentii'. Penelitian ini dilaksanakan di rumah kaca Fakultas Pertanian Universitas Riau. Penelitian ini dilakukan secara eksperimen dengan menggunakan Rancangan Acak Lengkap (RAL Faktorial) yang terdiri dari dua faktor yaitu jenis tanaman (S) dan media tanam (M), terdiri dari 6 perlakuan dan 3 ulangan sehingga diperoleh 18 unit penelitian. Perlakuan yang diberikan adalah M1S1 (tanah TPA $100 \%$, jenis S. aubrytiana 'Tiger'), M2S1 (tanah TPA $70 \%+$ kompos TKKS $30 \%$, jenis $S$. aubrytiana 'Tiger'), M3S1 (tanah TPA $70 \%$ + arang sekam $30 \%$, jenis S. aubrytiana 'Tiger'), M1S2 (tanah TPA $100 \%$, jenis S. trifasciata 'Laurentii'), M2S2 (tanah TPA $70 \%+$ kompos TKKS $30 \%$, jenis S. trifasciata 'Laurentii') dan M3S2 (tanah TPA $70 \%+$ arang sekam $30 \%$, jenis S. trifasciata 'Laurentii'). Data yang diperoleh kemudian diuji lanjut dengan uji jarak berganda Duncan pada taraf $5 \%$. Hasil penelitian menunjukkan bahwa tanah TPA-Sampah mampu menjadi alternatif pengganti tanah top-soil sebagai media tanam tanaman hias, terutama pada dua jenis tanaman Sansevieria. Kombinasi media tanam tanah TPA $70 \%$ + kompos TKKS $30 \%$ mampu meningkatkan tinggi tanaman, lebar daun dan jumlah daun tanaman pada kedua jenis tanaman Sansevieria. Sedangkan kombinasi media tanam tanah TPA $70 \%+$ arang sekam 30\% mampu meningkatkan jumlah anakan, berat segar tanaman dan volume akar pada kedua jenis tanaman Sansevieria.
\end{abstract}

Kata kunci : Sansevieria, Tanah TPA, Kompos TKKS, Arang sekam. 


\section{PENDAHULUAN}

Sansevieria merupakan tanaman hortikultura jenis tanaman hias dari famili Agavaceae. Di Indonesia tanaman ini cukup banyak dibudidayakan karena kesesuaian iklim dan letak geografis yang mendukung. Sansevieria lebih umum dikenal sebagai tanaman "lidah mertua" atau "tanaman ular" di Indonesia. Tanaman ini memiliki keistimewaan dibandingkan dengan tanaman hias lainnya yakni dapat bertahan dalam kondisi cuaca yang ekstrim seperti pada temperatur tinggi, kekurangan air, intensitas cahaya yang minim dan sangat toleran terhadap gas udara berbahaya (Purwanto, 2006). Badan Antariksa Amerika Serikat (NASA) menyatakan bahwa Sansevieria dapat menyerap unsur polutan berbahaya seperti karbon monoksida $(\mathrm{CO})$, timbal $(\mathrm{Pb})$, asap nikrotin, gas asam sulfida $\left(\mathrm{H}_{2} \mathrm{~S}\right)$, serta senyawa kimia berbahaya seperti kloroform, formaldehid, trikloroetilen, benzena dan xilen (Anonim, 2007). Dalam pembudidayaannya Sansevieria umumnya menggunakan media tanamcampuran tanah, pasir malang, pupuk organik, bahan organik (arang sekam, cocopeat, atau cacahan pakis) dengan variasi perbandingan tertentu (Balai Besar Pelatihan Pertanian Lembang, 2008). Sedangkan permasalahan yang seringkali dijumpai dalam kegiatan petanian salah satunya yakni ketersediaan tanah top soil sebagai media utama mengalami penurunan, (degradasi) akibat kegiatan pertanian baik dari segi kualitas maupun kuantitasnya (Rusdi et al., 2013). Sementara itu limbah hasil pertanian dan aktivitas manusia kian meningkat.

Beberapa limbah hasil pertanian yang sering dijumpai khususnya di Provinsi Riau adalah kompos tandan kosong kelapa sawit (TKKS) dan sekam padi, yang diketahui dapat memperbaiki struktur tanah baik secara fisik, kimia maupun biologisnya (Septiani, 2012). Sedangkan limbah hasil aktivitas manusia yang sering dijumpai berupa sampah hasil perkotaan maupun sampah rumah tangga. Sampah perkotaan tersebut kemudian dikelola dan dikumpulkan ke Tempat Pembuangan Akhir Sampah (TPA-S).

Sampah yang berada di TPA-S diketahui banyak mengandung zat organik dan anorganik hasil dekomposisi yang terjadi secara alamiah. seperti Besi (Fe) dan Seng (Zn) yang kebutuhannya esensial dan dapat dimanfaatkan bagi tanaman terutama bagi tanaman Sansevieria. Namun beberapa zat pencemar juga merembes kedalam tanah dan air tanah sehingga masyarakat menilai tanah yang berada di TPA-S beracun. Sedangkan unsur tersebut dapat dimanfaatkan oleh tanaman Sansevieria karena didukung oleh sifatnya yang tahan terhadap unsur toksik dan berkemampuan untuk menyerap unsur tersebut.

Penelitian ini bertujuan untuk mengetahui komposisi media tanam menggunakan tanah Tempat Pembuangan Akhir Sampah (TPA-S) yang terbaik untuk pertumbuhan tanaman Sansevieria jenis Sansevieria aubrytiana 'Tiger' dan Sansevieria trifasciata 'Laurentii'.

\section{METODOLOGI}

Penelitian ini telah dilaksanakan di rumah kaca Fakultas Pertanian Universitas Riau Kampus Bina Widya Km 12,5 Kelurahan Simpang Baru, Kecamatan Tampan, Kota Pekanbaru. Penelitian ini telah dilaksanakan pada bulan Juli sampai November 2018.

Bahan yang digunakan dalam penelitian ini adalah anakan tanaman Sansevieria jenis Sansevieria aubrytiana 'Tiger' dan Sansevieria trifasciata 'Laurentii' berumur \pm 5 bulan, arang sekam, kompos TKKS dan tanah dari TPA Sampah yang berasal dari Kelurahan Muara Fajar Kecamatan Rumbai Kota Pekanbaru.

Alat yang digunakan pada penelitian ini adalah pot tanaman terbuat dari plastik berwarna hitam dengan diameter $35 \mathrm{~cm}$, cangkul, ayakan ukuran 10 mesh, karung beras, timbangan, meteran, alat tulis dan alat dokumentasi.

Penelitian ini dilakukan secara eksperimen dalam bentuk percobaan faktorial 2 x 3 dengan menggunakan Rancangan Acak Lengkap (RAL Faktorial) yang terdiri dari dua faktor. Faktor pertama adalah spesies tanaman Sansevieria (S) dengan dua taraf yaitu $S_{1}$ (Sansevieria aubrytiana 'Tiger' ) dan $\mathrm{S}_{2}$ (Sansevieria trifasciata 'Laurentii').Faktor kedua adalah komposisi media tanam (M) yang terdiri dari tiga taraf yaitu $\mathrm{M}_{1}$ (Tanah TPA 100 $\%$ ), $\mathrm{M}_{2}$ (Tanah TPA $70 \%+$ Kompos TKKS 30 $\%$ ) dan $\mathrm{M}_{3}$ (Tanah TPA $70 \%$ + Arang Sekam $30 \%)$.

Berdasarkan perlakuan di atas diperoleh 6 kombinasi perlakuan, setiap perlakuan 
diulang sebanyak 3 kali sehingga diperoleh 18 unit percobaan. Setiap unit percobaan terdiri dari 3 tanaman Sansevieria dan 2 yang dijadikan tanaman sampel, sehingga keseluruhan penelitian ini terdiri dari 54 tanaman Sansevieria.

Parameter yang diamati adalah pertambahan tinggi tanaman, pertambahan lebar daun, pertambahan jumlah daun, pertambahan jumlah anakan, pertambahan berat segar tanaman dan volume akar.

Tabel 1. Analisis kandungan unsur hara pada tanah TPA-sampah di Kelurahan Muara Fajar, Kota Pekanbaru

\begin{tabular}{lll}
\hline \multicolumn{1}{c}{ Unsur hara } & \multicolumn{1}{c}{ Kandungan unsur hara } & Kriteria \\
\hline C-Organik & $1,77 \%$ & Rendah \\
N-Total & $0,20 \%$ & Rendah \\
P-Tersedia (fosfor) & $112,0 \mathrm{ppm}$ & Sangat Tinggi \\
$\mathrm{K}$ (kalium) & $2,12 \mathrm{cmol}(+) \mathrm{kg}^{-1}$ & Tinggi \\
$\mathrm{Mg}$ (magnesium) & $0.19 \mathrm{cmol}(+) \mathrm{kg}^{-1}$ & Sangat Rendah \\
$\mathrm{Ca}$ (kalsium) & $0,36 \mathrm{cmol}(+) \mathrm{kg}^{-1}$ & Sangat Rendah \\
$\mathrm{Na}$ (natrium) & $1,17 \mathrm{cmol}(+) \mathrm{kg}^{-1}$ & Sangat Tinggi \\
$\mathrm{KTK}$ & $6,07 \mathrm{cmol}(+) \mathrm{kg}^{-1}$ & Rendah \\
$\mathrm{C} / \mathrm{N}$ & 8,85 & Rendah \\
pH & 6,67 & Netral \\
$\mathrm{B}$ (boron) & $3,4 \mathrm{ppm}$ & - \\
Cu (tembaga) & $5,9 \mathrm{ppm}$ & - \\
Zn (seng) & $42,9 \mathrm{ppm}$ & - \\
Mn (mangan) & $22,4 \mathrm{ppm}$ & - \\
Fe (besi) & $3410 \mathrm{ppm}$ & - \\
Pasir & $84,8 \%$ & - \\
Liat & $8,6 \%$ & - \\
Debu & $6,6 \%$ & - \\
\hline
\end{tabular}

Dianalisis di Central Plantation Services (CPS) Pekanbaru (2018)

Tabel 1 memperlihatkan hasil analisis kandungan unsur hara yang terdapat pada tanah TPA-S kota Pekanbaru. Berdasarkan Tabel 1 dapat dilihat bahwa tanah TPA-S kota Pekanbaru memiliki kandungan C-Organik, NTotal, KTK dan nilai C/N yang rendah. Sedangkan kandungan $\mathrm{Mg}$ dan $\mathrm{Ca}$ tergolong sangat rendah, namun ketersediaan $\mathrm{P}$ dan $\mathrm{Na}$ pada tanah TPA-S kota Pekanbaru tergolong sangat tinggi diikuti oleh kandungan $\mathrm{K}$ yang tinggi. Selain itu terdapat juga beberapa unsur hara mikro pada tanah TPA-S kota Pekanbaru seperti besi (Fe) sebesar 3410 ppm, Seng ( $\mathrm{Zn}$ ) sebesar 42,9 ppm, Mangan (Mn) sebesar 22,4 ppm, Tembaga $(\mathrm{Cu})$ sebesar 5,9 ppm dan Boron (B) sebesar 3,4 ppm. Tanah TPA-S kota Pekanbaru diketahui memiliki $\mathrm{pH}$ netral yaitu sebesar 6,67. Sifat fisik tanah TPA-S kota Pekanbaru yang dianalisis berupa tekstur tanah

\section{HASIL DAN PEMBAHASAN}

\section{Analisis Tanah TPA-S Kota Pekanbaru}

Tanah yang berasal dari TPA-S Kota

Pekanbaru di analisis secara lengkap di Laboratorium Central Plantation Services (CPS) kota Pekanbaru. Hasil analisis tanah dapat dilihat pada Tabel 1. dengan kandungan pasir sebesar $84,8 \%$, liat $8,6 \%$ dan debu $6,6 \%$.

Kesuburan tanah dapat didefinisikan sebagai kemampuan tanah dalam menyediakan unsur hara dalam jumlah yang cukup dan tersedia bagi tanaman. Unsur hara tersedia bagi tanaman dalam bentuk ion yang kemudian dapat diserap oleh tanaman yang serapannya dipengaruhi oleh interaksi antara komponen fisika, kimia dan biologi tanah (Handayanto et al., 2017).

\section{Pertambahan Tinggi Tanaman}

Hasil sidik ragam menunjukkan bahwa pemberian perlakuan media tanam dan jenis tanaman berpengaruh nyata terhadap tinggi tanaman Sansevieria. Hasil uji lanjut dengan uji jarak berganda Duncan pada taraf $5 \%$ terhadap pertambahan tiggi tanaman dapat dilihat pada Tabel 2. 
Tabel 2. Pertambahan tinggi dua jenis tanaman Sansevieria umur 4 bulan setelah tanam pada tiga komposisi media tanam

\begin{tabular}{lcc}
\hline \multirow{2}{*}{ Perlakuan media tanam } & \multicolumn{2}{c}{ Perlakuan jenis tanaman } \\
\cline { 2 - 3 } & $\begin{array}{c}\text { S. aubrytiana } \\
\text { 'Tiger' }\end{array}$ & S. trifasciata 'Laurentii' \\
\hline Tanah TPA 100\% & $2,03 \mathrm{c}$ & $3,98 \mathrm{bc}$ \\
Tanah TPA 70 \% + kompos TKKS 30\% & $2,40 \mathrm{c}$ & $13,95 \mathrm{a}$ \\
Tanah TPA 70 \% + arang sekam 30\% & $1,92 \mathrm{c}$ & $8,33 \mathrm{~b}$ \\
\hline
\end{tabular}

Angka-angka yang diikuti oleh huruf kecil pada kolom yang sama tidak berbeda nyata menurut uji jarak berganda Duncan pada taraf $5 \%$.

Tabel 2 menunjukkan bahwa tanaman Sansevieria aubrytiana 'Tiger' tidak memperlihatkan peningkatan tinggi tanaman yang nyata pada keseluruhan perlakuan komposisi media tanam, namun pada perlakuan komposisi media tanam tanah TPA $70 \%+$ kompos TKKS $30 \%$ tanaman cenderung mengalami pertambahan tinggi yang lebih baik dibandingkan dengan perlakuan komposisi media tanam lainnya dengan pertambahan tinggi sebesar $2,40 \mathrm{~cm}$. Sedangkan pada tanaman Sansevieria trifasciata 'Laurentii' perlakuan komposisi media tanam dapat meningkatkan tinggi tanaman secara nyata. Komposisi media tanam tanah TPA $70 \%+$ kompos TKKS $30 \%$ memperlihatkan pertambahan tinggi tanaman tertinggi yaitu sebesar $13,95 \mathrm{~cm}$ dan berbeda nyata dengan perlakuan komposisi media tanam tanah TPA $100 \%$, namun berbeda tidak nyata dengan perlakuan komposisi media tanam tanah TPA $70 \%$ + arang sekam $30 \%$.

Berdasarkan hasil penelitian ini, pemberian media tanam tanah TPA yang dikombinasikan dengan kompos TKKS menunjukkan pertambahan tinggi yang baik pada kedua jenis tanaman Sansevieria. Ketersediaan hara esensial yang terkandung dalam kompos TKKS mampu di absorbsi dengan baik oleh perakaran tanaman sehingga metabolisme berjalan optimal.

Unsur Nitrogen berperan penting dalam pertumbuhan vegetatif tanaman karena dapat merangsang pertumbuhan secara keseluruhan (Lingga dan Marsono, 2003). Selain Nitrogen, ketersediaan Fosfor dan Kalium juga memiliki peran penting dalam memacu pertumbuhan tinggi tanaman, Fosfor berperan dalam pembelahan sel sehingga memacu pertumbuhan tanaman, pemasakan biji serta mampu memberi ketahanan pada tanaman terhadap penyakit akar. Sedangkan Kalium penting bagi tanaman dalam proses pembukaan dan penutupan stomata sehingga tanaman tahan terhadap cekaman salinitas, dapat meningkatkan efisiensi pemupukan Nitrogen (Munawar, 2011).

Kurniawan et al. (2014) menyatakan bahwa kandungan unsur hara yang terdapat dalam kompos TKKS berupa N-Total $(2,15$ $\%), \mathrm{P}_{2} \mathrm{O}_{5}$-Total $(1,54 \%), \mathrm{K}_{2} \mathrm{O}(0,15 \%)$ dan COrganik $(14,50 \%)$ mampu menyokong pertumbuhan tanaman. Sementara itu Pusat Penelitisn Kelapa Sawit (2003) menyatakan bahwa $\mathrm{C} / \mathrm{N}$ yang terkandung dalam kompos TKKS mendekati kandungan $\mathrm{C} / \mathrm{N}$ tanah yakni dengan kandungan $\mathrm{C} / \mathrm{N} 15$ sehingga dapat memudahkan tanaman dalam penyerapan unsur hara. Ketersediaan Nitrogen yang cukup dapat menunjang pertumbuhan tanaman khususnya pada pembentukan batang dan daun tanaman (Lingga dan Marsono, 2001). Ketersediaan unsur $\mathrm{N}$ total dalam kompos TKKS TASPU yang digunakan dalam penelitian ini sebesar 2,45\% dan merupakan unsur kedua terbanyak setelah unsur Karbon (C) (Lampiran 4).Hardjowigeno (2010) menyatakan bahwa ketersediaan unsur hara akan optimal apabila tanah memiliki tekstur yang baik seperti struktur tanah, permeabilitas tanah, porositas dan lain-lain, yang kemudian akan mengakibatkan aerasi disekitar media tanam menjadi lebih baik sehingga tanaman mampu memperluas sistem perakarannya untuk menunjang pertumbuhan tanaman.

\section{Pertambahan Lebar Daun}

Tabel 3 menunjukkan bahwa pada tanaman Sansevieria aubrytiana 'Tiger' perlakuan komposisi media tanam dapat meningkatkan lebar daun tanaman secara nyata, Komposisi media tanam Tanah TPA 70 $\%$ + kompos TKKS $30 \%$ memperlihatkan pertambahan lebar daun tanaman tertinggi yaitu sebesar $0,83 \mathrm{~cm}$ dan berbeda nyata dengan perlakuan komposisi media tanam tanah TPA $100 \%$. Sedangkan tanaman Sansevieria trifasciata 'Laurentii' tidak memperlihatkan peningkatan lebar daun tanaman yang nyata pada keseluruhan perlakuan komposisi media tanam, namun 
pada perlakuan komposisi media tanam tanah TPA $70 \%$ + kompos TKKS $30 \%$ tanaman cenderung mengalami pertambahan lebar daun yang lebih baik dibandingkan dengan perlakuan komposisi media tanam lainnya dengan pertambahan lebar daun sebesar 0,87 $\mathrm{cm}$.

Tabel 3. Pertambahan lebar daun dua jenis tanaman Sansevieria umur 4 bulan setelah tanam pada tiga komposisi media tanam.

\begin{tabular}{lcc}
\hline \multirow{2}{*}{ Perlakuan media tanam } & \multicolumn{2}{c}{ Perlakuan jenis tanaman } \\
\cline { 2 - 3 } & $\begin{array}{c}\text { S. aubrytiana } \\
\text { 'Tiger' }\end{array}$ & S. trifasciata 'Laurentii' \\
\hline Tanah TPA $100 \%$ & $0,13 \mathrm{~b}$ & $0,60 \mathrm{ab}$ \\
Tanah TPA 70 \% + kompos TKKS 30\% & $0,83 \mathrm{a}$ & $0,87 \mathrm{a}$ \\
Tanah TPA 70\%+ arang sekam 30\% & $0,63 \mathrm{ab}$ & $0,68 \mathrm{ab}$ \\
\hline
\end{tabular}

Angka-angka yang diikuti oleh huruf kecil pada kolom yang sama tidak berbeda nyata menurut uji jarak berganda Duncan pada taraf $5 \%$.

Media tanah yang dicampur dengan kompos TKKS diketahui mampu menopang pertumbuhan tanaman karena ketersediaan hara yang lengkap seperti Nitrogen (N), Fosfor (P), Kalium (K), Kalsium (Ca), Magensium $(\mathrm{Mg})$, Belerang $(\mathrm{S})$, Besi (Fe), Tembaga $(\mathrm{Cu})$, Seng (Zn), Klor (Cl), Boron (B), Molibdenium (Mo) dan unsur lainnya (Mustaqim et al., 2016). Nitrogen merupakan penyusun utama biomassa tanaman muda dan berperan dalam merangsang pertumbuhan daun, selain Nitrogen unsur Magnesium diketahui juga dapat merangsang pertumbuhan daun karena perannya sebagai penyusun klorofil yang berguna dalam proses fotosintesis (Nyakpa et al., 1986 dalam Fauzi dan Puspita, 2017).

Sansevieria diketahui memiliki kemampuan yang khas dibandingkan dengan tanaman lainnya yakni kemampuan dalam menyerap unsur polutan. Hal tersebut sesuai dengan penelitian yang dilakukan oleh Setyawan dan Surya (2017) dimana tanaman Sansevieria mampu menyerap logam berat seperti Tembaga $(\mathrm{Cu})$ sebanyak $11 \mathrm{ppm}$ atau sekitar 35,4\% dari 31 ppm konsentrasi $\mathrm{CuSO}_{4}$ yang telah dicemarkan kedalam media tanam.

\section{Pertambahan Jumlah Daun}

Hasil sidik ragam menunjukkan bahwa pemberian perlakuan media tanam dan jenis tanaman berpengaruh nyata terhadap jumlah daun tanaman Sansevieria. Hasil uji lanjut dengan uji jarak berganda Duncan pada taraf 5 $\%$ terhadap pertambahan jumlah daun tanaman dapat dilihat pada Tabel 4.

Tabel 4. Pertambahan jumlah daun dua jenis tanaman Sansevieria umur 4 bulan setelah tanam pada tiga komposisi media tanam

\begin{tabular}{ccc}
\hline Perlakuan media tanam & \multicolumn{2}{c}{ Perlakuan jenis tanaman } \\
\cline { 2 - 3 } & $\begin{array}{c}\text { S. aubrytiana } \\
\text { 'Tiger' }\end{array}$ & $\begin{array}{c}\text { S. trifasciata } \\
\text { 'Laurentii' }\end{array}$ \\
\hline Tanah TPA 100 \% & $1,67 \mathrm{ab}$ & $0,83 \mathrm{~b}$ \\
Tanah TPA 70 \% + kompos TKKS 30\% & $2,50 \mathrm{a}$ & $2,67 \mathrm{a}$ \\
Tanah TPA 70 \% + arang sekam 30\% & $1,33 \mathrm{ab}$ & $2,50 \mathrm{a}$ \\
\hline
\end{tabular}

Angka-angka yang diikuti oleh huruf kecil pada kolom yang sama tidak berbeda nyata menurut uji jarak berganda Duncan pada taraf $5 \%$.

Tabel 4 menunjukkan bahwa tanaman Sansevieria aubrytiana 'Tiger' tidak memperlihatkan peningkatan jumlah daun tanaman yang nyata pada keseluruhan perlakuan komposisi media tanam, namun pada perlakuan komposisi media tanam tanah TPA $70 \%+$ kompos TKKS $30 \%$ tanaman cenderung mengalami pertambahan jumlah daun yang lebih baik dibandingkan dengan perlakuan komposisi media tanam lainnya dengan pertambahan jumlah daun tanaman sebanyak 2,50 helai. Sedangkan pada tanaman
Sansevieria trifasciata 'Laurentii' perlakuan komposisi media tanam dapat meningkatkan jumlah daun tanaman secara nyata. Komposisi media tanam tanah TPA $70 \%+$ kompos TKKS $30 \%$ memperlihatkan pertambahan jumlah daun tanaman terbanyak yaitu sebanyak 2,67 helai dan berbeda nyata dengan perlakuan komposisi media tanam tanah TPA $100 \%$, namun berbeda tidak nyata dengan perlakuan komposisi media tanam tanah TPA $70 \%+$ arang sekam $30 \%$. Hal ini diduga karena penambahan kompos TKKS pada media tanam mampu memperbaiki sifat fisik, 
kimia maupun biologi tanah, selain itu ketersediaan unsur $\mathrm{N}$ dalam tanah dapat terpenuhi sehingga mampu meningkatkan pertumbuhan vegetatif tanaman.

Hasil penelitian yang telah dilakukan oleh Fauzi dan Puspita (2017), menyimpulkan bahwa pemberian kompos TKKS pada media tanam mampu meningkatkan jumlah daun tanaman sawit sebesar 26,30\%. Kecukupan pasokan $\mathrm{N}$ dalam tanaman ditandai dengan aktivitas fotosintesis yang tinggi dan pertumbuhan vegetatif yang baik (Munawar, 2011). Hakim (1986) dalam Fauzi dan Puspita (2017) menyatakan bahwa nitrogen berperan dalam pembentukan sel-sel dan klorofil yang kemudian berguna dalam proses fotosintesis dan dapat menghasilkan energi yang dapat dimanfaatkan oleh sel tanaman dalam aktivitas pembelahan, pembesaran dan pemanjangan sel. Selain ketersediaan unsur $\mathrm{N}$, ketersediaan unsur $\mathrm{P}$ dalam kompos TKKS juga berperan dalam peningkatan jumlah daun tanaman. Unsur $\mathrm{P}$ diketahui mampu mempercepat perkembangan tanaman, sebagai komponen penting dalam penyusunan senyawa untuk transfer energi serta dapat merangsang pertumbuhan daun tanaman (Novizan, 2002).
Kalium (K) juga memiliki peran dalam pertumbuhan jumlah daun tanaman, berdasarkan penelitian yang telah dilakukan oleh Ayunis et al. (2015) pemberian pupuk organik cair (POC) lindi yang berasal dari dekomposisi sampah di Tempat Pembuangan Akhir (TPA) Batam menyebabkan pertambahan jumlah daun tanaman Seledri yang lebih baik dibandingkan dengan pemberian pupuk organik cair pembanding. Kalium memiliki peran dalam pembukaan dan penutupan stomata serta berperan dalam aktivator beberapa enzim yang terlibat dalam sintesis protein dan karbohidrat, apabila kandungan Kalium meningkat maka karbohidrat untuk pertumbuhan tanaman juga akan meningkat sehingga dapat menunjang pertumbuhan tanaman (Salisbury dan Ross, 1995 dalam Fauzi dan Puspita, 2017).

\section{Pertambahan Jumlah Anakan}

Hasil sidik ragam menunjukkan bahwa pemberian perlakuan media tanam dan jenis tanaman berpengaruh tidak nyata terhadap jumlah anakan tanaman Sansevieria. Hasil uji lanjut dengan uji jarak berganda Duncan pada taraf $5 \%$ terhadap pertambahan jumlah anakan tanaman dapat dilihat pada Tabel 5.

Tabel 5. Pertambahan jumlah anakan dua jenis tanaman Sansevieria umur 4 bulan setelah tanam pada tiga komposisi media tanam.

\begin{tabular}{lcc}
\hline \multirow{2}{*}{ Perlakuan media tanam } & \multicolumn{2}{c}{ Perlakuan jenis tanaman } \\
\cline { 2 - 3 } & $\begin{array}{c}\text { S. aubrytiana } \\
\text { 'Tiger' }\end{array}$ & $\begin{array}{c}\text { S. trifasciata } \\
\text { 'Laurentii' }\end{array}$ \\
\hline Tanah TPA $100 \%$ & $0,83 \mathrm{ab}$ & $0,00 \mathrm{~b}$ \\
Tanah TPA 70\%+ kompos TKKS 30\% & $1,33 \mathrm{a}$ & $0,67 \mathrm{ab}$ \\
Tanah TPA 70 $\%+$ arang sekam 30\% & $1,17 \mathrm{ab}$ & $1,17 \mathrm{ab}$ \\
\hline
\end{tabular}

Angka-angka yang diikuti oleh huruf kecil pada kolom yang sama tidak berbeda nyata menurut uji jarak berganda Duncan pada taraf $5 \%$.

Tabel 5 menunjukkan bahwa tanaman Sansevieria aubrytiana 'Tiger' tidak memperlihatkan peningkatan jumlah anakan tanaman yang nyata pada keseluruhan perlakuan komposisi media tanam, namun pada perlakuan komposisi media tanam tanah TPA $70 \%$ + arang sekam $30 \%$ tanaman cenderung mengalami pertambahan jumlah anakan yang lebih baik dibandingkan dengan perlakuan komposisi media tanam lainnya dengan pertambahan jumlah anakan tanaman sebesar 1,67 batang. Sedangkan pada tanaman Sansevieria trifasciata 'Laurentii' perlakuan komposisi media tanam tidak dapat meningkatkan jumlah anakan tanaman secara nyata. Namun pada perlakuan komposisi media tanam tanah TPA $70 \%$ + arang sekam $30 \%$ memperlihatkan pertambahan jumlah anakan tanaman yang lebih baik dibandingkan dengan perlakuan komposisi media tanam lainnya dengan pertambahan jumlah anakan sebanyak 1,17 batang.

Berdasarkan hasil penelitian yang dilakukan diketahui bahwa pada perlakuan media tanam yang dikombinasikan dengan arang sekam mampu meningkatkan pertambahan jumlah anakan tanaman Sansevieria. Arang sekam umumnya digunakan dalam budidaya tanaman hias untuk mengurangi penggunaan tanah top-soil karena memiliki sifat yang ringan (berat jenis $=0,2$ $\mathrm{kg} . \mathrm{l}^{-1}$ ), memiliki banyak pori (porous) sehingga sirkulasi udara dan daya serap tinggi, berwarna coklat kehitaman sehingga dapat mengabsorbsi 
sinar matahari serta dapat berfungsi dalam pengikatan hara saat tanah dalam kondisi kelebihan unsur hara dan akan dilepaskan secara perlahan (slow release) apabila tanah kekurangan unsur hara sesuai dengan dosis yang diperlukan oleh tanaman (Supriyanto dan Fidryaningsih, 2010). Supriyanto dan Fidryaningsih (2010) menjelaskan bahwa penambahan arang sekam dapat meningkatkan panjang akar tanaman Jabon karena dengan penambahan arang sekam dapat memperbaiki struktur tanah menjadi lebih gembur. Hal tersebut memungkinkan perakaran tanaman Sansevieria dapat tumbuh dengan baik karena kondisi media yang porous sehingga mata tunas baru akan lebih mudah tumbuh dan terbentuk anakan yang baru. Perbanyakan tanaman Sansevieria secara vegetatif salah satunya dilakukan dengan penanaman anakan tanaman (Tahir dan Sitanggang, 2008).

\section{Pertambahan Berat Segar Tanaman}

Hasil sidik ragam menunjukkan bahwa pemberian perlakuan media tanam dan jenis tanaman berpengaruh nyata terhadap pertambahan berat segar tanaman Sansevieria. Hasil uji lanjut dengan uji jarak berganda Duncan pada taraf $5 \%$ terhadap pertambahan berat segar tanaman tanaman dapat dilihat pada Tabel 6.

Tabel 6. Pertambahan berat segar dua jenis tanaman Sansevieria umur 4 bulan setelah tanam pada tiga komposisi media tanam

\begin{tabular}{lcc}
\hline \multirow{2}{*}{ Perlakuan media tanam } & \multicolumn{2}{c}{ Perlakuan jenis tanaman } \\
\cline { 2 - 3 } & $\begin{array}{c}\text { S. aubrytiana } \\
\text { 'Tiger' }\end{array}$ & $\begin{array}{c}\text { S. trifasciata } \\
\text { 'Laurentii' }\end{array}$ \\
\hline Tanah TPA $100 \%$ & $279,67 \mathrm{ab}$ & $109,67 \mathrm{c}$ \\
Tanah TPA 70 $\%+$ kompos TKKS 30\% & $248,83 \mathrm{abc}$ & $123,17 \mathrm{bc}$ \\
Tanah TPA 70 $\%+$ arang sekam 30\% & $322,17 \mathrm{a}$ & $178,17 \mathrm{abc}$ \\
\hline
\end{tabular}

Angka-angka yang diikuti oleh huruf kecil pada kolom yang sama tidak berbeda nyata menurut uji jarak berganda Duncan pada taraf $5 \%$.

Tabel 6 menunjukkan bahwa tanaman Sansevieria aubrytiana 'Tiger' tidak memperlihatkan peningkatan berat segar tanaman yang nyata pada keseluruhan perlakuan komposisi media tanam, namun pada perlakuan komposisi media tanam tanah TPA $70 \%$ + arang sekam $30 \%$ tanaman cenderung mengalami pertambahan berat segar tanaman yang lebih baik dibandingkan dengan perlakuan komposisi media tanam lainnya dengan pertambahan berat segar tanaman sebesar 322,17 g. Sedangkan pada tanaman Sansevieria trifasciata 'Laurentii' perlakuan komposisi media tanam tidak dapat meningkatkan berat segar tanaman secara nyata. Namun pada perlakuan komposisi media tanam tanah TPA $70 \%$ + arang sekam $30 \%$ memperlihatkan pertambahan berat segar tanaman yang lebih baik dibandingkan dengan perlakuan kombinasi media tanam lainnya dengan pertambahan berat segar tanaman sebesar 178,12 g.

Pertambahan berat segar tanaman Sansevieria sangat erat kaitannya dengan pertambahan jumlah anakan tanaman. Berdasarkan Tabel 5, jumlah anakan tanaman terbesar diperoleh pada pemberian kombinasi media tanam tanah TPA $70 \%$ yang dicampur dengan arang sekam 30\% dengan jenis tanaman Sansevieria aubrytiana 'Tiger' maupun jenis Sansevieria trifasciata 'Laurentii'. Menurut Tahir dan Sitanggang (2008) kesesuaian jenis tanah mempengaruhi penyerapan dan perluasan rambut akar, media tanam yang baik bagi pertumbuhan tanaman Sansevieria terdiri atas campuran humus, pasir, pakis dan sekam bakar dengan perbandingan 1 $: 2: 1: 1$. Sukaryorini dan Arifin (2007) dalam Irawan dan Kafiar (2015) menambahkan bahwa arang sekam mampu memberikan respons yang lebih baik terhadap berat basah tanaman maupun berat kering tanaman.

Nur et al. (2016) menambahkan bahwa akar merupakan faktor terpenting dalam meningkatkan berat kering tanaman karena dianggap berfungsi sebagai penyerapan unsur hara, air dan mineral penting dalam tanah. Keterkaitan antara berat kering dan berat segar tanaman adalah keduanya merupakan hasil dari proses pertumbuhan dan perkembangan yang dapat diamati kuantitasnya. Berat segar merupakan hasil pengukuran dari berat segar biomassa tanaman sebagai akumulasi bahan yang dihasilkan selama pertumbuhan (Buntoro et al., 2014). 


\section{Volume Akar}

Hasil sidik ragam menunjukkan bahwa pemberian perlakuan media tanam dan jenis tanaman berpengaruh nyata terhadap volume akar tanaman Sansevieria. Hasil uji lanjut dengan uji jarak berganda Duncan pada taraf 5 $\%$ terhadap volume akar tanaman dapat dilihat pada Tabel 7.

Tabel 7. Pertambahan volume akar dua jenis tanaman Sansevieria umur 4 bulan setelah tanam pada tiga komposisi media tanam

\begin{tabular}{lcc}
\hline \multirow{2}{*}{ Perlakuan media tanam } & \multicolumn{2}{c}{ Perlakuan jenis tanaman } \\
\cline { 2 - 3 } & $\begin{array}{c}\text { S. aubrytiana } \\
\text { 'Tiger' }\end{array}$ & S. trifasciata 'Laurentii' \\
\hline Tanah TPA 100\% & $49,17 \mathrm{bc}$ & $11,67 \mathrm{c}$ \\
Tanah TPA 70 \% + kompos TKKS 30\% & $65,83 \mathrm{ab}$ & $27,50 \mathrm{bc}$ \\
Tanah TPA 70 $\%+$ arang sekam 30\% & $98,33 \mathrm{a}$ & $28,33 \mathrm{bc}$ \\
\hline An
\end{tabular}

Angka-angka yang diikuti oleh huruf kecil yang sama pada kolom yang sama tidak berbeda nyata menurut uji jarak berganda Duncan pada taraf $5 \%$.

Tabel 7 menunjukkan bahwa pada tanaman Sansevieria aubrytiana 'Tiger' perlakuan komposisi media tanam dapat meningkatkan volume akar tanaman seacara nyata. Komposisi media tanam tanah TPA 70 $\%$ + arang sekam $30 \%$ memperlihatkan pertambahan volume akar tanaman tertinggi yaitu sebanyak $98,33 \mathrm{ml}$ dan berbeda nyata dengan perlakuan kombinasi media tanam tanah TPA $100 \%$, namun tidak berbeda nyata dengan perlakuan kombinasi media tanam tanah TPA $70 \%+$ kompos TKKS $30 \%$. Sedangkan tanaman Sansevieria trifasciata 'Laurentii' tidak memperlihatkan peningkatan volume akar tanaman yang nyata pada keseluruhan perlakuan komposisi media tanam, namun pada perlakuan komposisi media tanam tanah TPA $70 \%$ + arang sekam $30 \%$ tanaman cenderung mengalami pertambahan volume akar yang lebih baik dibandingkan dengan perlakuan komposisi media tanam lainnya dengan pertambahan volume akar sebesar 28,33 ml.

Pramono (2008) menyatakan bahwa jenis media tanam yang sesuai untuk tanaman Sansevieria adalah media yang memiliki banyak pori, bertekstur kasar dan sedikit mengandung bahan organik. Irawan dan Kafiar (2015) menyatakan bahwa pemberian arang sekam memiliki pengaruh yang lebih besar terhadap peningkatan perkembangan akar bibit Cempaka Wasian dibandingkan dengan pertumbuhan pucuk yang berefek pada pertumbuhan tajuk. Hasil penelitian Kusuma et al. (2013) menyebutkan bahwa penambahan pembenah tanah arang sekam maupun abu sekam sebanyak $50 \%$ kedalam tanah liat dapat meningkatkan panjang akar lateral. Semakin banyak bahan pembenah yang ditambahkan maka semakin banyak pula ruang pori tanah yang dapat ditembus oleh akar sehingga lebih mudah tumbuh untuk mencari hara.

\section{KESIMPULAN DAN SARAN}

\section{Kesimpulan}

1 Berdasarkan penelitian yang telah dilakukan dapat disimpulkan bahwa tanah TPA-Sampah mampu menjadi alternatif pengganti tanah top-soil sebagai media tanam tanaman hias, terutama pada dua jenis tanaman Sansevieria yaitu Sansevieria aubrytiana 'Tiger' dan Sansevieria trifasciata 'Laurentii'.

2 Penggunaan kombinasi media tanam secara keseluruhan memberikan dampak yang cukup baik bagi pertumbuhan dua jenis tanaman Sansevieria, kombinasi media tanam tanah TPA $70 \%+$ kompos TKKS $30 \quad \%$ terbukti mampu meningkatkan tinggi tanaman, lebar daun dan jumlah daun tanaman pada jenis Sansevieria aubrytiana 'Tiger' dan Sansevieria trifasciata 'Laurentii'.

3 Kombinasi media tanam campuran tanah TPA $70 \%$ + arang sekam 30\% dapat meningkatkan jumlah anakan, berat segar tanaman dan volume akar pada jenis Sansevieria aubrytiana 'Tiger' dan Sansevieria trifasciata 'Laurentii'.

\section{Saran}

Berdasarkan penelitian yang telah dilakukan untuk pembudidayaan tanaman Sansevieria khususnya pada jenis Sansevieria aubrytiana 'Tiger' dan Sansevieria trifasciata 'Laurentii' dapat menggunakan media tanam pengganti seperti tanah TPA-S yang dicampur dengan media sekunder seperti kompos TKKS dan arang sekam. 


\section{DAFTAR PUSTAKA}

Anonim. 2007. Agar Tanaman Hias Tampil Cantik. Agromedia Pustaka. Jakarta.

Ayunis, M., Puspita, L., Notowinarno. 2015. Pengaruh Pemberian Pupuk Organk Cair (Air Lindi) Terhadap Pertumbuhan Morfometrik Tanaman Seledri (Apium graveolensi L.). Jurnal Simbiosa. 4(1): 27-34.

Balai Besar Pelatihan Pertanian Lembang (BBPP). 2008. Sansevieria. www.bbpplembang.info/index.php. Diakses tanggal 2 April 2018.

Buntoro, B. H., Rogomulyo, R., Trisnowati, S. 2014. Pengaruh Takaran Pupuk Kandang dan Intensitas Cahaya Terhadap Pertumbuhan dan Hasil Temu Putih (Curcuma zedoaria L.). Jurnal Vegetalika. 3(4): 29-39.

Central Plantation Services. 2018. Analisa Tanah TPA-sampah dari Kelurahan Muara Fajar Kota Pekanbaru. PT. Central Alam Resources Lestari. Pekanbaru.

Fauzi, A., dan Puspita, F. 2017. Pemberian Kompos TKKS dan Pupuk P Terhadap Pertumbuhan Bibit Kelapa Sawit (Elaeis guineensis Jacq.) di Pembibitan Utama. Jom Faperta. 4(2): 1-12.

Hardjowigeno, S. 2010. Ilmu Tanah. Akademika Pressindo. Jakarta.

Irawan, A. dan Kafiar, Y. 2015. Pemanfaatan cocopeat dan Arang Sekam Padi Sebagai Media Tanam Bibit Cempaka Wasian (Elmerrillia ovalis)

Kurniawan, R., Ratna, R. L., Sanggam, S. dan Chairani, H. 2014. Tanggap Pertumbuhan dan Produksi Jagung Manis Pada Pemberian Mikroorganisme Bermanfaat dan Kompos Tandan Kosong Kelapa Sawit. Jurnal Online Mahasiswa Agroteknologi. 2(3): 11721181.

Kusuma, A. H., Izzati, M., Septiningsih, E. (2013). Pengaruh Penambahan Arang dan Abu Sekam Dengan Proporsi Yang Berbeda Terhadap Permeabilitas dan Porositas Tanah Liat Serta Pertumbuhan Kacang Hijau (Vigna radiata L.). Jurnal Anatomi dan Fisiologi. 21(1): 1-9.

Lingga, P. dan Marsono. 2003. Petunjuk Penggunaan Pupuk. Penebar Swadaya. Jakarta.
Munawar, A. 2011. Kesuburan Tanah dan Nutrisi Tanaman. IPB Press. Bogor.

Mustaqim, R., Armaini dan A. E. Yulia. 2016. Pengaruh Pemberian Kompos Tandan Kosong Kelapa Sawit dan Pupuk N, P,K Terhadap Pertumbuhan dan Produksi Tanaman Melon (Cucumis melo L.) Jurnal Online Mahasiswa Fakultas Pertanian Universitas Riau. 3(1): 1-13

Novizan. 2002. Petunjuk Pemupukan yang Efektif. Agromedia pustaka. Jakarta.

Nur, M., Jumin, B. H., Maizar, M. 2016. Pertumbuhan Tanaman Ceplukan (Physalis angulata L.) Pada Tanah Tercemar Limbah Bleaching Earth Dengan Remediasi Pupuk Kandang. Jurnal Dinamika Pertanian. 32(1): 3550.

Pramono, S. 2008. Pesona Sansevieria. Agromedia Pustaka. Jakarta.

Purwanto, A. W. 2006. Sansevieria Flora Cantik Penyerap Racun. Kanisius. Yogyakarta.

Pusat Penelitian Kelapa Sawit (PPKS). 2003. Produksi Kompos Dari Tandan Kosong Kelapa Sawit. Pusat Penelitian Kelapa Sawit. Medan.

Septiani, D. 2012. Pengaruh Pemberian Arang Sekam Padi terhadap Pertumbuhan dan Hasil Tanaman Cabai Rawit (Capsicum frutescens). Politeknik Negeri Lampung. Lampung.

Setyawan, A. dan Surya, Y. 2017. Pemanfaatan Tanaman Lidah Mertua (Sansevieria trifasciata) untuk Absorbsi Tembaga $(\mathrm{Cu})$ Industri Peleburan Tembaga. Jurnal Envirotek. 9(1): 13-21.

Supriyanto dan Fidryaningsih, F. 2010. Pemanfaatan Arang Sekam Untuk Memperbaiki Semai Jabon (Anthocepalus cadamba (Roxb) Miq) pada Media Subsoil. Jurnal Silvikultur Tropika. 1(1): 24-28. 
